\title{
A new species of genus Cucujus Fabricius, 1775 (Coleoptera: Cucujidae) from China
}

\author{
JiŘí HÁVA ${ }^{1,2}$, PETR ZAHRADNÍK ${ }^{3}$ \& TOMÁŠ RŮŽIČKA ${ }^{4}$ \\ ${ }^{1}$ Daugavpils University, Institute of Life Sciences and Technology, \\ Department of Biosystematics, Vienības Str. 13, Daugavpils, LV - 5401, LATVIA \\ ${ }^{2}$ Private Entomological Laboratory and Collection, \\ Rýznerova 37, CZ - 25262 Únětice u Prahy, Praha-západ, Czech RePuBlic \\ e-mail: jh.dermestidae@volny.cz \\ ${ }^{3}$ Forestry and Game Management Research Institute \\ Strnady 136, CZ-150 00 Praha 5 - Zbraslav, Czech RePubliC \\ e-mail: zahradnik@vulhm.cz \\ ${ }^{4}$ Central Institute for Supervising and Testing in Agriculture, \\ Division of Protection against Harmful Organisms, \\ Ztracená 1099/10, CZ-16100 Praha 6, CzECH RePuBliC \\ e-mail: tomas.ruzicka@ukzuz.cz
}

Háva, J., Zahradník, P. \& RŮŽIČKA, T.: A new species of genus Cucujus Fabricius, 1775 (Coleoptera: Cucujidae) from China.

Abstract: Cucujus janatai sp. nov. from Yunnan, China is described, illustrated and compared with other Chinese species. A key to the known Chinese species of Cucujus Fabricius, 1775 is provided.

Keyword: Taxonomy, new species, Coleoptera, Cucujidae, Cucujus, China, Yunnan

\section{Introduction}

There are thirteen species and three subspecies of Cucujus Fabricius, 1775 from the family Cucujidae which range across the Holarctic and Oriental Regions (WEGRZYNOWICZ 2007, Lee \& Satô 2007, Lee \& Pütz 2008, Horák \& Сhobot 2009, Zhao \& Zhang 2019). The aim of the present paper is to describe a new species from Yunnan province, China and all of the recognized Chinese species are keyed.

\section{Material and methods}

The following abbreviations are used to define the deposition of the holotype and paratypes:

FGMRI - Forestry and Game Management Research Institute, Jíloviště, Czech Republic (Petr Zahradník); JHAC - Jiř́ Háva, Private Entomological Laboratory \& Collection, Únětice u Prahy, Prague-west, Czech Republic;

MJPC - Miroslav Janata, private collection, Prague, Czech Republic; 
PZAC - Petr Zahradník, private collection, Prague, Czech Republic;

TRAC - Tomáš Růžička, private collection, Prague, Czech Republic.

Specimens of the presently described species are provided with a red printed label with the following text: "HOLOTYPE [or PARATYPE] Cucujus janatai sp. nov. J. Háva, P. Zahradník \& T. Růžička det. 2019”.

\section{Description}

\section{Cucujus janatai sp. nov. (Figs. 1-8)}

Type material. Holotype (ðึ): China, NW Yunnan, valley $12 \mathrm{~km} \mathrm{SW}$ of Dongwangxiang Mts S of Huoiu vill., N 28 25" 08'", E 99³6'45"', 4390 m, 26-31.5.2019, lgt. R. Sehnal \& M. Janata, (FGMRI). Paratypes: (7 spec.): same data as holotype, $(1$ ô, 1 o PZAC, 2

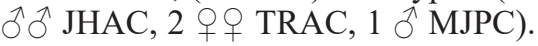

Description. Male (Fig. 1). Body length $13.2 \mathrm{~mm}$. Color: dorsal and ventral surfaces dark red and black, setae black.

Head (Figs. 2-3): dark red with black labrum, clypeus and anterior part, triangular, distinctly wider than pronotum; dorsal surface with dense and large punctures, somewhat converging near fronto-clypeal area, rather closer and rounded on vertex, reduced on temples, front margins of clypeus and areas above antennal insertions smooth, occipital furrow dull, eyes strongly projecting and highly convex; moderately covered with short black setae, clypeus with several pairs of long setae; ventral surface smooth, with quite sparse and minute punctures, genae and mentum bearing scattered, moderate-sized punctures; genae with short setae which are converging on the front and genal horns, mentum moderately setose, each side with several long setae; temples well swollen. Mandibles black (Fig. 3). Antennae black with 11 antennomeres covered by black setation.

Pronotum (Fig. 2) dark red, each lateral margin with 7-9 tubercles; with broad median cruciate depression; punctures dense and large, closer and prominent on depressions, rather reduced on margins, area around posterior angles abruptly dull with several minute punctures; with mainly moderate or short setae, with long setae along lateral margins.

Scutellar shield: black, obtuse-pentagonal, slightly wider than long; with irregular, close and small punctures and circular depression.

Elytra (Fig. 1): dark red, elongate, finely punctured, with very short setae along margins, setae longer near apex of elytron.

Legs: black, with scattered and small punctures, somewhat larger on femora; with moderate and short setae converging near apices of tibiae.

Abdomen: black, with confused and small punctures, smooth near sutures; abdominal sterna bearing moderate setae, posterior margin of fifth sternum with long setae.

Pygidium: black, with small and regular punctures; with short setae, setae prolonged near apex.

Male genitalia as in Figs. 5-6.

Female. Externally similar to male. Body length $15 \mathrm{~mm}$. Female genitalia as in Figs. 7-8.

Variability. Body length 12-15 mm. 
Diagnosis. The new species differs from other known Chinese Cucujus species by the charactersistics in the following key.

Etymology. Patronymic, dedicated to the collector of the new species, Miroslav Janata (Prague, Czech Republic).

Bionomy. Specimens collected at an altitude of $4390 \mathrm{~m}$, under and on the bark of Abies sp. Type locality as in Figs. 8-9 (Photo by R. Sehnal).

Distribution. China: Yunnan province.

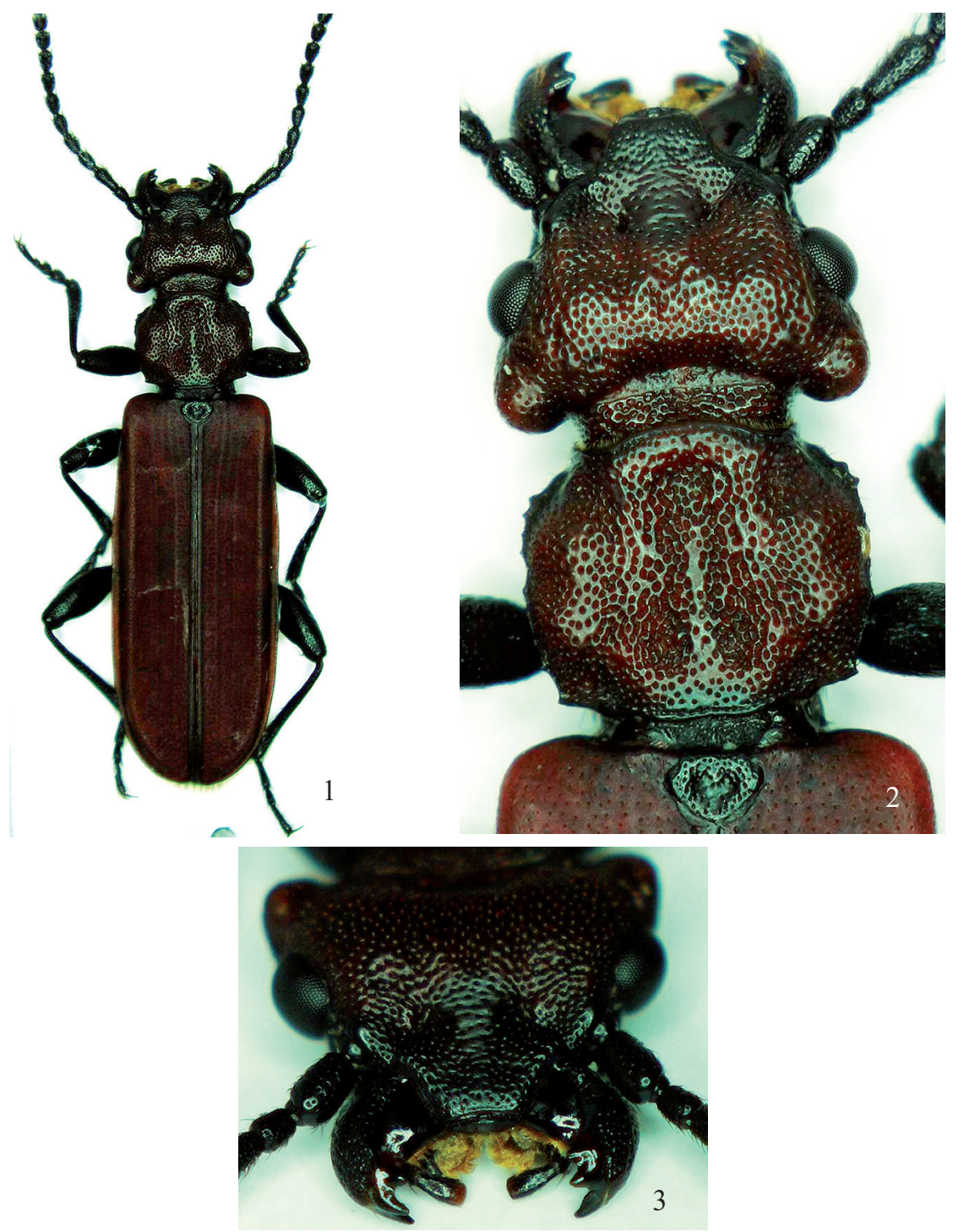

Figs. 1-2: Cucujus janatai sp. nov.: 1- habitus, dorsal aspect; 2- head, pronotum and scutellum; 3 - head with mandibles 


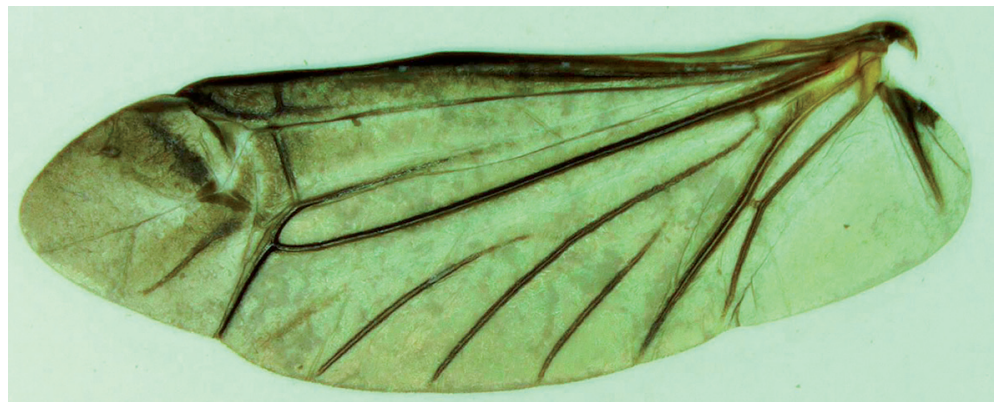

Fig. 4: Cucujus janatai sp. nov. wing

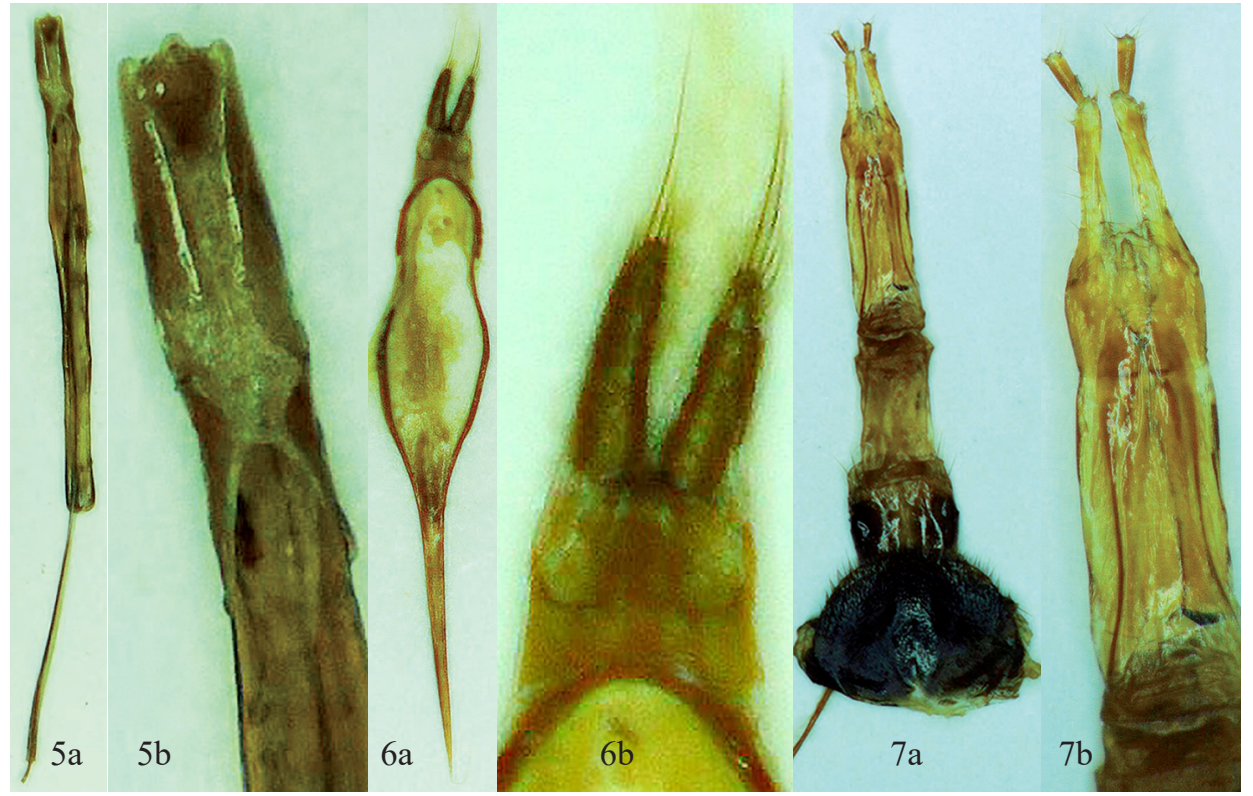

Figs. 5-7: Cucujus janatai sp. nov.: 5a,b- median lobe; 6a,b- parameres; $7 \mathbf{a}, \mathbf{b}$ - female genitalia 

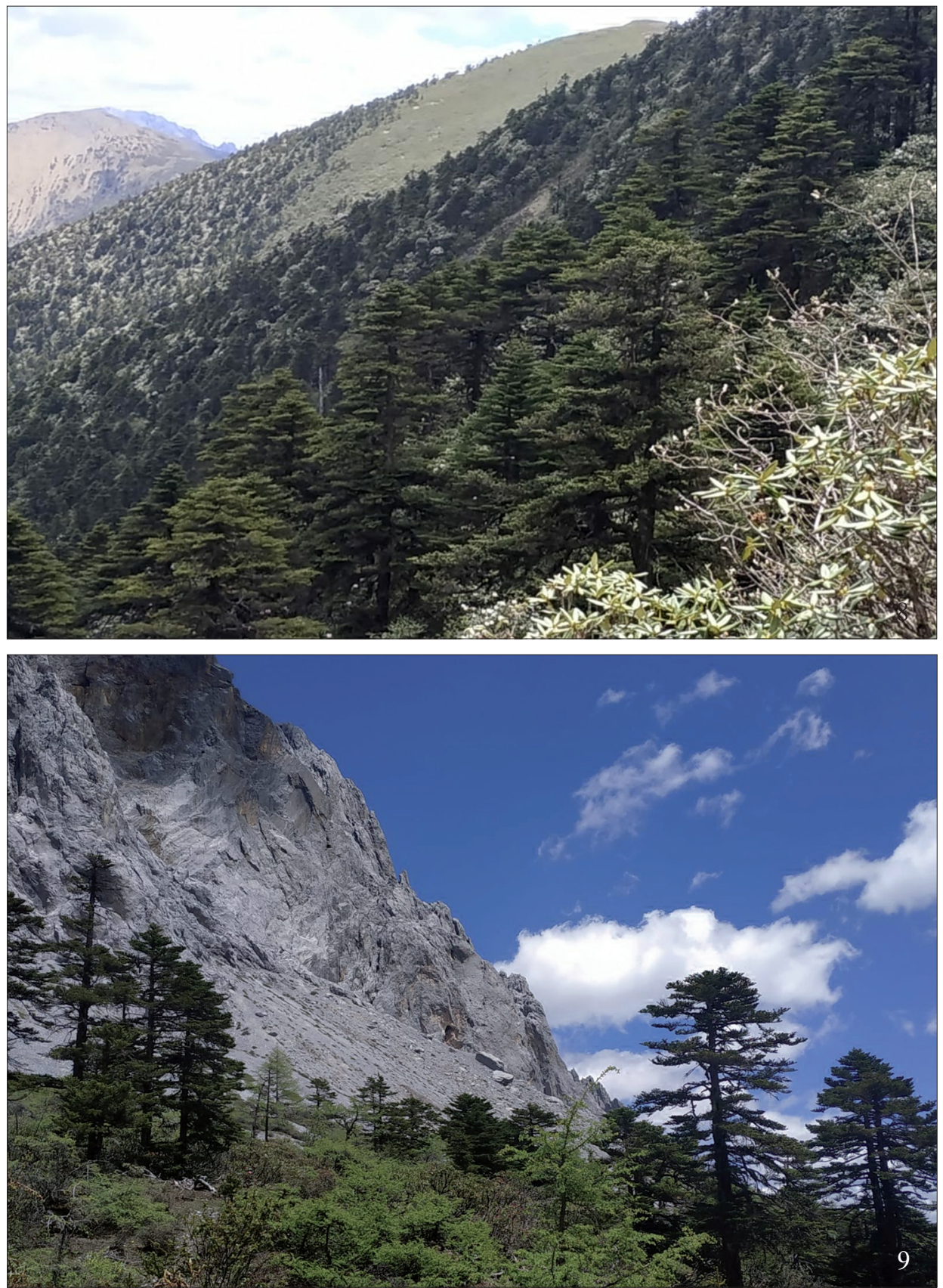

Figs. 8-9: Type locality of Cucujus janatai sp. nov., China: NW Yunnan 


\section{Modified key to Chinese Cucujus species}

1. elytra with longitudinal and elevated carinae .... C. costatus Zhao \& Zhang, 2019

- elytra without elevated structures, sometimes with vague longitudinal lines .........2

2. temples nearly horizontal, weakly produced posteriorly ............................... 3

- temples swollen, distinctly produced posteriorly ................................... 4

3. pronotal surface with tubercles; both elytra about 2.6 times as long as wide

C. chinensis Lee \& Satô, 2007

- pronotum with indistinct depressions; both elytra about 2.9 times as long as wide

C. elongatus Lee \& Pütz, 2008

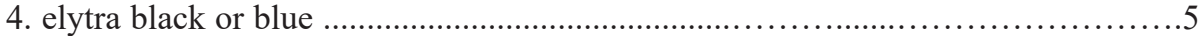

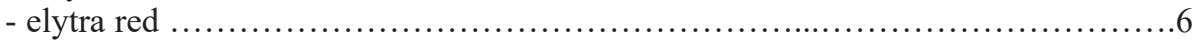

5. legs black; elytra blue with fine punctures $19.6-24.7 \mathrm{~mm}$

C. mniszechi Grouvelle, 1874

- legs dark brown; elytra black with prominent punctures; length 15.3-17.2 mm

C. nigripennis Lee \& Satô, 2007

6. pronotum wider than head, with prominent denticles ..... C. kempi Grovelle, 1913

- pronotum narrower than head with rather small denticles .7

7. head and pronotum black; anterior angles of pronotum subrectangular

C. haematodes opacus Lewis, 1888

- head and pronotum red

8. scutellum red; labrum red; mandibles red

C. haematodes haematodes Erichson, 1845

- scutellum black; labrum black; mandibles black C. janatai sp. nov.

\section{Acknowledgements}

We are very indebted to the collectors for the bionomy information and photos of the type locality. We would like to thank J. D. Fenton (U.K., London for language editing). The paper was supported by the Ministry of Agriculture of the Czech Republic, Institutional support MZE-RO0118.

\section{References}

HorÁk, J. \& СНовот, K. 2009: Worldwide distribution of saprpxylic beetles of the genus Cucujus Fabricius, 1775 (Coleoptera: Cucujidae). - In: Buse, J., Alexander, K., Ranius, T. \& Assmann, T. (eds.): Proceedings of the 5th Symposium and Workshop on the Conservation of Saproxylic Beetles. SofiaMoscow: Pensoft Publishers, pp. 189-206.

LeE, C. F. \& Pütz, A. 2008: A new species of Cucujus Fabricius, 1775 from China and key to the east-palaerctic species of the genus (Coleoptera: Cucujidae). - Entomologische Zeitschrift 118(5): 211-213.

Lee, C. F. \& Satô, M. 2007: A Review of the Genus Cucujus Fabricius (Insecta: Cucujoidea: Cucujidae) from Taiwan, Japan, and China with Description of Two New Species and the Larvae of Cucujus mniszechi Grouvelle. - Zoological Studies 46(3): 311-321.

Wegrzynowicz, P. 2007: Cucujidae, pp. 502-503. In: Löbl I. \& Smetana A. (eds.): Catalogue of Palaearctic Coleoptera. Volume 4. Elateroidea - Derodontoidea - Bostrichoidea - Lymexyloidea - Cleroidea and Cucujoidea. - Stenstrup: Apollo Books, 935 pp.

ZhaO, M-Z. \& Zhang, J-K. 2019: Contribution to the knowledge of the genus Cucujus Fabricius (Coleoptera,Cucujidae) from China. - Zootaxa 4544(1): 144-150. 